\title{
10 Protecting Whistleblowers: the Roles of Public and Private International Law
}

\author{
Dr Dimitrios Kagiaros. \\ Teaching Fellow in Public Law and Human Rights, University of Edinburgh \\ Dr Amanda Wyper, \\ Lecturer in Commercial Law, University of Edinburgh
}

\subsection{Introduction}

Financial crime, corruption and financial scandals are often revealed to the public by whistleblowers, ${ }^{1}$ individuals who in the course of their work become aware of information relating to misconduct, abuses of power or corruption and decide to alert the relevant authorities or the press. ${ }^{2}$ After proceeding to such disclosures of misconduct, whistleblowers are commonly exposed to retaliatory measures which may involve the imposition of employment or criminal sanctions for breaching the duty of confidentiality usually associated with employment. ${ }^{3}$ There is growing recognition amongst states that whistleblowers are in need of protection from such retaliation. Many states are in the process of developing whistleblower protection frameworks that offer legal remedies for any detriment to which the whistleblower was exposed for proceeding to a disclosure. ${ }^{4}$ These protections are usually found in employment law or dedicated statutes. ${ }^{5}$ Many private institutions also adopt internal whistleblowing policies to offer assurances to anyone reporting information in the public interest, to prevent them being retaliated against.

A particularly complicated area of whistleblower protection relates to whistleblowers who proceed to disclosures with a cross-border element, especially in instances where a worker is temporarily posted 6 in a country 'other than that whose

\footnotetext{
1 'How to help whistleblowers' The Economist (London, 8 December 2015)

<https://www.economist.com/blogs/freeexchange/2015/12/money-talks-0> accessed 7 October 2017.

See also 'The Age of the Whistleblower' The Economist (Lonodn, 3 December 2015)

<http://www.economist.com/news/business/21679455-life-getting-better-those-who-exposewrongdoing-companies-continue-fight> accessed 7 October 2017.

2 Whistleblowing can be defined as 'the reporting by employees or former employees of illegal, irregular, dangerous or unethical practices by employers'. International Labour Organisation, 'ILO Thesaurus' <http://www.ilo.org/thesaurus/defaulten.asp> accessed 7 October 2017. On whistleblowing more broadly see M Miceli and J Near, Blowing the Whistle: The Organizational and Legal Implications for Companies and Employees (New York: Lexington Books, 1992), S Bok, 'Whistleblowing and Professional Responsibility', in P Tittle (ed), Ethical Issues in Business: Inquiries, Cases, and Readings (Ontario: Broadview Press, 2000).

${ }^{3}$ For research on the various forms of employment-related sanctions and other forms of retaliation whistleblowers can be exposed to, see A Fred, Whistleblowers: Broken Lives and Organizational Power (Ithaca, NY: Cornell University Press, 2001) and Peter B. Jubb, 'Whistleblowing: A Restrictive Definition and Interpretation' (1999) 21 Journal of Business Ethics 77.

${ }^{4}$ On this see World Law Group, 'Global Guide to Whistleblowing Programs' (2016)

<http://www.gop.it/doc_pubblicazioni/616_ub5zro2b1w_ita.pdf> accessed 7 October 2017.

5 Ibid.

${ }^{6}$ On the distinction between permanent and temporary workers see LC Piñeiro, 'Labour Migration and Private International Law' in V Ruiz Abou-Nigm et all (eds), Diversity and Integration in Private International Law (Edinburgh, EUP, forthcoming). See also Regulation (EC) 2008/593 of the European Parliament and of the Council of 17 June 2008 on the law applicable to contractual obligations (Rome I)
} 
law is the governing law of the contract [of employment]'. ${ }^{7}$ When such whistleblowers proceed to a public interest disclosure, what protection can they expect and from which of the legal systems related to the disclosure? What happens where the whistleblower protection in the country of disclosure is less advanced than the law governing the contract of employment? In their seminal work on this issue, Hyde and Savage illustrate the complications for whistleblower protection that arise in such disclosures that involve a cross-jurisdictional element. ${ }^{8}$ Building on this account, this contribution aims to, first, identify the private international law concerns that cross-border whistleblowing generates, and secondly, argue that public international law has the potential to incentivise states to find solutions to some of those concerns. This is due to the fact that there is a clear trend in international human rights law to recognise that unwarranted retaliation against whistleblowers who proceed to public interest disclosures constitutes a violation of their right to freedom of expression, thus reflecting the normative 'traveller' from public international law to private international and national law explained by d'Aspremont and Giglio. ${ }^{9}$ This may require states to become increasingly involved in cross-border whistleblowing and to be more vigilant and proactive in ensuring that no individual within their jurisdiction is faced with treatment that may violate their free speech rights. Human rights law, however, is not a panacea in this context. As this contribution explains, there are significant limitations to the capability of human rights law to effectively address all issues raised by cross-border disclosures. The authors argue that in spite of these limitations, public international law can play an important role in bringing some coherence to the fragmented nature of cross-border whistleblowing. Therefore, this scenario allows for a thorough examination of the interplay between private and public international law.

The structure of the chapter is as follows. The first section considers issues of protection and regulatory design in whistleblowing regulation, using examples of cases which highlight the difficulties that arise for whistleblowing in a cross-border setting. The focus is on the financial services industry, as this is an industry which frequently encounters cross-border dealings and movement of employees and, consequently, jurisdictional issues for employees and protective private legislation. This section draws examples from regulatory design in the UK. The regulatory approach of the UK, as an example of a major financial centre, is considered here. Relying on the UK as an example also allows us to examine these issues through the lens of a state that is comprised of multiple sub-state entities. This will set the stage for a presentation of the private international law issues surrounding cross-border whistleblowing, before the chapter discusses the contribution of public international law in protecting whistleblowers from retaliation. The second section examines the contribution of public international law in this context. It begins by analysing the relationship between freedom of expression and whistleblowing in order to determine the obligations states have to protect whistleblowers from detriment. This leads to an examination of the responsibilities

OJ L 177/6; M McParland, The Rome I Regulation on the Law Applicable to Contractual Obligations (Oxford, Oxford University Press, 2015); B Yüksel, 'The Relevance of the Rome I Regulation to International Commercial Arbitration in the European Union' (2011) 7 Journal of Private International Law 149.

7 R Hyde and A Savage 'Whistleblowing without Borders: the Risks and Rewards of Transnational Whistleblowing Networks' in DLewis and WVandekerckhove (eds), Developments in Whistleblowing Research 2015 (London: International Whistleblowing Research Network, 2015).

8 Ibid.

${ }^{9}$ See the chapter by D'Aspremont and Giglio in this volume. 
under international human rights law of the various states involved in the disclosure. Ultimately, the research shows that despite human rights protection may fail to provide effective solutions to all problems raised by disclosures in a cross-border setting, it serves as an impetus for further state cooperation on the matter.

\subsection{Regulatory approaches to whistleblowing: protection and incentives}

Financial regulation relies to some extent on business compliance and also on investigatory work by regulators. As it would be prohibitively expensive for national regulators to fully investigate the workings of authorised firms and institutions, regulation relies on an element of self-disclosure of compliance and also noncompliance. Reliance, however, is also placed on workers as 'informational conduits' 10 to assist regulators in identifying where resources should be targeted, and which firms should be investigated. Workers are increasingly relied upon for information-gathering, and have become a valuable component of the regulatory toolkit in the design of financial and other regulatory regimes. Information detailing corruption and financial crime is usually well-hidden. It can therefore be difficult for regulators to identify such misconduct and large-scale, industry-wide problems, such as the personal pensions scandal or the payment protection scandal, both in the 1990s, may go undetected. ${ }^{11}$ New regulation often specifically provides for protection of whistleblowers on the basis that employees may be best placed to understand the workings of an organisation and may be better than regulators at identifying issues of concern that are in need of further investigation. ${ }^{12}$ In order for the workers to be effective in this regulatory design, adequate protection and incentives for the whistleblower must be in place.

The problems associated with effective whistleblower protection are magnified where there is a cross-border element to the disclosure. The legal provisions of the law governing the employment contract may dictate that it is not possible for any remedies provided to the whistleblower to have extra-territorial effect or it may simply be the case that regulators are only concerned with activity within their own borders and would be unable to provide protection for retaliation the whistleblower is subjected to in a third country. If whistleblowers have concerns about their protection, then this will lead to an unwillingness to report wrongdoing. ${ }^{13}$

\subsection{Domestic UK whistleblowing regulation}

In the UK statutory protection relating to disclosures in the public interest is found in the Employment Rights Act 1996 (ERA) as amended by the Public Interest Disclosure Act 1998 (PIDA). ${ }^{14}$ This statutory regulation is applicable in all three legal systems in

\footnotetext{
${ }^{10}$ A Savage and R Hyde, 'The Response to Whistleblowing by Regulators: A Practical Perspective' 35 Legal Studies (2015) 408.

$11 \mathrm{~J}$ Black and R Nobles, 'Personal Pension Misselling: The Causes and Lessons of Regulatory Failure' (1998) 61 MLR 789.

12 The Pensions Act 2008 s56 makes specific detriment provisions in relation to auto-enrolment pensions and section 43F ERA 1996 makes provision for protection of whistleblowers where they report to the Pensions Regulator.

13 The Whistleblowing Commission, 'Report on the effectiveness of existing arrangements for workplace whistleblowing in the UK' (November 2013).

14 Whilst the Scottish and English legal systems are distinct, much of the financial regulation and employment law statues apply on a UK-wide basis subject to interpretation in the usual way by the
} 
the UK, ie England and Wales, Scotland and Northern Ireland. PIDA introduced protection from dismissal or other detriment for workers who make a protected disclosure relating to misconduct they have uncovered in the workplace. ${ }^{15}$ PIDA does not generate an obligation for workers to speak up. This approach illustrates the balance between formal hard law regulation and soft law encouragement of appropriate culture and behaviour. ${ }^{16}$ Parliamentary debates ${ }^{17}$, on the statutory reforms and compensation limits, acknowledged that it takes 'special courage and a special person to blow the whistle in the workplace'18 and that cases such as the Maxwell scandal and the Bank of Credit and Commercial International ${ }^{19}$ in the 1990s before the passage of the Act underlined the need to protect those reporting wrongdoing in confidence. In treating the compensation for whistleblower dismissal differently from ordinary unfair dismissal, Parliament recognised the difficult position of whistleblowers and also tried to effect the cultural change by encouraging reporting of misconduct.

In addition to trying to protect employees from detriment, the use of positive financial whistleblowing incentives, like those offered in the US, ${ }^{20}$ has recently been considered and rejected in the UK, with the exception of whistleblowers providing information about cartels. ${ }^{21}$ It was considered that the financial incentives would not increase the quality of whistleblowing and that instead the approach of improving behaviour in financial services was to be followed. The way of dealing with negative consequences of whistleblowing is therefore to regulate the contractual relationships and obligations between parties through private law. A contract of employment will require the employee to be loyal and keep the confidence of the employer, but whistleblowing may protect the employee from suffering detriment for breaching this confidence in prescribed circumstances.

To be protected, the worker must make a qualifying disclosure ${ }^{22}$ whilst having a reasonable belief that it is required because of the occurrence of a criminal offence, breach of legal duties, miscarriage of justice, health and safety breaches, environmental damage or a general belief that the disclosure is in the public interest. ${ }^{23}$ Depending on the identity of the party the disclosure is made to, further conditions may need to be satisfied. ${ }^{24}$ For example, if the disclosure is made to an industry regulator, such as the Financial Conduct Authority, the worker must also believe that the matter falls within

\footnotetext{
separate legal systems of the UK. This is due to the fact that most aspects of employment are a matter reserved to the UK Parliament, see Scotland Act 1998 s5.

${ }^{15}$ Employment Rights Act 1996 (ERA) s43B.

${ }^{16}$ See chapter 5 for further consideration of soft law. Parliamentary consideration of the compensation limits and legislative intention highlights this objective to encourage whistleblowing and better behaviours.

17 HC Deb 30 March 1999, vol 328, cols 875-82.

18 ibid Mr Healy, col 879.

19 Financial Conduct Authority (FCA) and Prudential Regulation Authority (PRA), 'Financial Incentives for Whistleblowers: Note by the Financial Conduct Authority (FCA) and the Prudential Regulation Authority (PRA) for the Treasury Select Committee' (July 2014) availble at <https://www.fca.org.uk/publication/financial-incentives-for-whistleblowers.pdf> accessed 7 October 2017.

${ }^{20}$ Introduced by the Dodd-Frank Wall Street Reform and Consumer Protection Act Pub L No 111-203,

124 Stat 1376 (2010) (codified at 15 U.S.C 78o (2012)).

21 FCA \& PRA, 'Financial Incentives for Whistleblowers' 7.

22 43J(1) of ERA 1996 prevents contractual obligations preventing a protected disclosure.

23 ERA 1996, s43.

24 ERA 1996, s43C.
} 
the supervision and control of that regulatory body and also that that the information and allegations are true. ${ }^{25}$ A disclosure to the employer would simply need to follow the internal policy guidance on whistleblowing. As indicated previously, there is no financial cap on compensation in whistleblowing claims, and no requirement for a minimum period of service in the UK. From a private international law perspective, this could make the choice of law of Scots, English or the law of Northern Ireland more attractive from the employee perspective as a choice of law for the contract of employment. The attraction of unlimited compensation may mean that, in practice, the link between a particular complaint and a protected disclosure may sometimes be tenuous. It may encourage individuals to claim detriment under the whistleblowing provisions rather than under ordinary unfair dismissal where this is more appropriate. This may also have an impact on construction of the legislation as being for employment protection for the purposes of international private law rules. Workers must also be sure that the action is protected by the legislation as the disclosure of confidential information outside the prescribed protection is likely to amount to a breach of contract. $^{26}$

The domestic UK whistleblowing legislation protects a category of 'worker' wider than just employees ${ }^{27}$ and relies on the contractual relationship and worker status, which may vary in different jurisdictions. Volunteers, interns, non-executive directors and those classed as self-employed will be excluded from the definition and protection; but some categories of worker usually excluded from the definition of employee, such as agency workers, police officers and some additional categories of health service workers, are protected. The differing levels of protection and exclusions in domestic legislation further complicates the rights of individual whistleblowers in cross-border cases and makes the legal position more difficult to understand without specialist legal advice. Even legal specialists may find the law unclear. For example, it was understood that partners in a limited liability partnership were not workers for the purposes of statutory UK employment protection until a recent UK Supreme Court decision reversed that, stating that partners of a Limited Liability Partnership are indeed considered to be within the category of 'workers' for the purpose of whistleblowing protection. ${ }^{28}$ This caused difficulties in a number of areas of employment law but highlights the desire to cover a broad scope of situations to encourage whistleblowing.

In order to satisfy the protection provisions ${ }^{29}$ a certain standard of disclosure must be made and workers may not be protected if they pursue acts of misconduct in order to gather evidence. ${ }^{30}$ The legislative approach is to encourage internal disclosure to employers whilst allowing some protection for workers making an external disclosure to certain prescribed persons. Good faith was also a prerequisite for

\footnotetext{
25 ERA 1996, s43.

${ }_{26}$ Brandeaux Advisers (UK) Limited, Brandeaux Managers Limited, Brandeaux Administrators Limited $v$ Ruth Chadwick [2010] EWHC 3241 (QB).

27 ERA 1996, s230(3).

${ }^{28}$ Clyde \& Co LLP v Bates van Winkelhof [2014] UKSC 32.

${ }^{29}$ ERA 1996, S43L(3).

${ }^{30}$ Aspinall v MSI Mech Forge Ltd [2002] UKEAT 891. See also Bolton School v Evans [2006] EWCA (Civ) 1653, where a prospective whistleblower was found responsible for misconduct for hacking into his employer's IT system to prove that it was not secure.
} 
protection until 2013 but is no longer required. ${ }^{31}$ Whistleblowers must now demonstrate that the disclosure was made in the reasonable belief of the whistleblower that the disclosure is in the public interest.

Domestic legislation offers protection to the whistleblower if the claim is brought in the courts of the legal systems of the United Kingdom and the law of England, Scotland or Northern Ireland results applicable to the contract of employment. These are two separate questions that need to be analysed taking into account the private international law rules applicable in these legal systems. This contribution turns to these issues next.

\subsection{Private International Law}

When bringing a claim under the detriment provisions before an Employment Tribunal $^{32}$ in the UK in cross-border cases questions of jurisdiction and choice of law both arise. The main issues in relation to temporary workers and whistleblowers present in the field of applicable law discussed below. It is important to note that, whilst the UK legislation envisages protection under its whistleblowing framework for workers -a particularly broad category that as discussed above includes volunteers, interns and others-, when we consider the private international law rules on jurisdiction and choice of law our focus is on individual contracts of employment. ${ }^{33}$ The chapter will proceed to examine the issues relating to jurisdiction and applicable law in turn.

\subsubsection{Jurisdiction}

Matters of jurisdiction are determined by the Brussels I bis Regulation when the defendant is domiciled in the EU, or there is a choice of court agreement selecting the courts of the UK, or the Brussels I bis Regulation is otherwise engaged, for example, because the courts in England, Scotland or Northern Ireland have exclusive jurisdiction, irrespective of the domicile of the defendant. ${ }^{34}$ If the Brussels I bis Regulation is not applicable, the rules of jurisdiction would be different depending on whether the issue is before the courts in England, Scotland or Northern Ireland, as these separate legal systems have their own jurisdictional rules different from each other for disputes outside the scope of application of the Brussels I bis Regulation or the 2007 Lugano Convention. In turn, an employment tribunal in the UK, can only hear a case if England, Scotland or Northern Ireland have jurisdiction to hear the case according to private

\footnotetext{
31 Enterprise and Regulatory Reform Act (ERRA) 2013, pt 2 para 18.

32 Governed by the Employment Tribunals (Constitution and Rules of Procedure) Regulations 2013 (SI 2013/1237), Employment Tribunals have jurisdiction to hear claims set out in the Employment Tribunals Act 1996, the jurisdiction of employment tribunals in England and Wales, and those in Scotland, is governed by Employment Tribunal Rules.

${ }^{33}$ Different legal systems will have different criteria to identify a contract of employment but this may lead to uncertainty or conflicts where a worker is considered an employee, for whistleblower purposes, in one legal system but not another.

${ }^{34}$ Regulation (EU) No 1215/2012 of the European Parliament and of the Council of 12 December 2012 on jurisdiction and the recognition and enforcement of judgments in civil and commercial matters (recast), OJ L 351/1, 20 December 2012 (Brussels I bis).
} 
international law rules, either the Brussels I bis Regulation, the Lugano Convention, or the respective national jurisdiction rules. Where the Brussels or Lugano regimes do not apply, the determination on the issue of jurisdiction would be decided following the English common law rules of jurisdiction and the Civil Jurisdiction and Judgements Act 1982, in England and Scotland, respectively. With regard to the determination of jurisdiction at the sub-state level, Schedule 4 of the 1982 Act contains the "rules for allocation of jurisdiction within the UK" (intra-UK jurisdiction) ${ }^{35}$, while Schedule 8 provide the Scottish traditional rules on jurisdiction outwith the EU, the UK and the Lugano Convention states. In the case of Scotland, Schedule 8 also explicitly identifies the rules for 'individual contracts of employment'. ${ }^{36}$

This analysis, however, reflects the regime that is followed when Brussels regime applies. If the Brussels I bis Regulation is applicable, the relevant provisions on jurisdiction for individual contracts of employment are in Section 5 (arts 20-23). The core protection for the employee is provided for in art 21 that allows the employee to bring proceedings against the employer either in the courts of the employer's domicile or (i) in the courts of the place where or from where the employee habitually carries out his work, or in the last place where he did so; or (ii) if the employee does not have a habitual place of work, in the courts of the place where the business which engaged the employee is or was situated.

In the whistleblower scenario, the employee may also need to consider defending an action for breach of confidentiality by the employer. For cases where Brussels I bis applies, an employer may only bring proceedings in the courts of a Member State where the employee is domiciled. ${ }^{37}$ So if we were to have a whistleblower, domiciled in London, working for a company based in Scotland who is engaged to work in Abu Dhabi one month out of two, working from England the other month, the employee should have a jurisdiction option as a result of the application these rules. If the employee suffers detriment as a consequence of whistleblowing he could raise an action in Scotland, as place of employer's domicile or perhaps England as place where the employee is engaged and situated. If the employer wanted to raise an action to enforce confidentiality provisions, the employer would have to raise an action in England as place of domicile of the employee. This situation would be governed by Schedule 4 of the 1982 Act. However, if the employer was a company domiciled in France, the Brussels I bis Regulation would apply; if the employer was domiciled in Switzerland the 2007 Lugano Convention would govern; and if the employer was domiciled in the US then Schedule 8 of the 1982 Act would provide the jurisdiction framework. It is to be noted that while there are certain differences between these regimes they are indeed very similar in the treatment of jurisdiction for individual contracts of employment. Hence, all these regimes provide that the whistleblower in our scenario would be able to bring his or her case of unfair dismissal in the courts of the place where the employer

\footnotetext{
${ }^{35}$ See further chapter by K Hoods in this collection.

${ }^{36}$ Civil Jurisdiction and Judgments Act 1982 Schedule 8 s4.

${ }^{37}$ Brussels I Bis (n 34) art 22.
} 
is domiciled, 38 or "in the courts for the place where the employee habitually carries out his work or in the courts for the last place where he did so", 39 or "if the employee does not or did not habitually carry out his work in any one place, in the courts for the place where the business which engaged the employee is or was situated". 40 Under these provisions, the employer could only bring proceedings against the whistleblower, (for breach of confidence for instance) "in the courts of the place in which the employee is domiciled". 41

It would be for then for the courts of Scotland, England or Norther Ireland, respectively to determine the law applicable to the proceedings, considering the nature of the contract, its special contractual terms, such as the existence of a choice of law clause, and the relevant private international law rules, namely the Rome I Regulation. In light of this, the subsequent section will examine the issues that arise in relation to the determination of the applicable law.

\subsubsection{Applicable law}

Matters of choice of law in disputes involving individual contracts of employment are determined by the Rome I Regulation. The Regulation is to be applied by the courts of all Member States of the EU even if the application of those rules results in a non-EU law being the governing law or where some or all of the parties to the dispute are nonEuropean. The Regulation provides for individual contracts of employment to be governed by the law of the habitual place of work. ${ }^{42}$ This regime has been designed with permanent labour migration in mind; resorting to the habitual place of work as the connecting factor is not particularly helpful for temporary workers. ${ }^{43}$ However, employee and employer could agree on a more convenient law to govern their contract. Since employees are considered to be weaker parties a choice of law cannot deprive the employee of the protection afforded by non-derogable provisions of the law that would govern in the absence of choice of law ${ }^{44}$ In addition, the employee is protected from having the country of habitual work being changed by temporary employment in another country. ${ }^{45}$ The European regime also provides for an escape to the lex loci laboris in favour of a closer law. 46 The private international law approach is, therefore, flexible, to allow for the specific circumstances of individual workers.

\footnotetext{
${ }^{38}$ Brussels I Bis (n 34) art 21-22, Lugano Convention on Jurisdiction and the recognition and enforcement of judgments in civil and commercial matters 2007 art 19-20, and at the domestic level, Civil Jurisdiction and Judgments Act 1982 Schedule 4 s10 and Schedule 8 s4.

${ }^{39}$ Civil Jurisdiction and Judgments Act 1982 Schedule 8 s4(2)(b).

${ }^{40}$ Civil Jurisdiction and Judgments Act 1982 Schedule 8 s(2)(c).

${ }^{41}$ Ibid s4(3).

${ }^{42}$ Rome I Reg (n 6) art 8. For the different considerations underpinning the selection of the habitual place of work see Carballo, 'Labour Migration' (n 6).

${ }^{43}$ Carballo, 'Labour Migration' (n 6).

${ }^{44}$ Nevertheless, as workers are considered to be weaker parties a choice of law cannot deprive the employee of the protection afforded by the mandatory provisions of the law that would govern in the absence of choice of law, as required by art 8 Rome I Reg.

${ }^{45}$ Rome I Reg (n 6) art 8(2).

${ }^{46}$ Ibid art 8(4).
} 
The most relevant questions in relation to whistleblowers concern the concept of domestic provisions non-derogable by agreement, as provided for in art 8 of the Rome I Regulation, and the concept of overriding mandatory provisions as defined in art 9 of the Regulation. ${ }^{47}$ In relation to art 8 of the Rome I Reg (providing for the governing law of the habitual place of work), the provisions of employment statutes would be in most cases within the remit of the second indent of art 8 (1), that is, provisions that cannot be derogated from by agreement, if the habitual place of work is in the UK. Moreover, these provisions may in some cases be even considered overriding mandatory provisions. The latter, according to Art 9 (1) of the Rome I Regulation are provisions "the respect for which is regarded as crucial by a country for safeguarding its public interests, such as its political, social or economic organisation, to such an extent that they are applicable to any situation falling within their scope, irrespective of the law otherwise applicable to the contract". In considering whether to give effect to these provisions as non-derogable (art 8(1)) or overriding mandatory provisions (art 9 (1)) the nature and purpose of the provisions is considered. ${ }^{48}$ Statutory provisions containing employee protections, such as the Employment Rights Act, are likely to be included within the non-derogable category. ${ }^{49}$

Rome I, however, also provides in Article 21, that "the application of a provision of the law of any country specified by this Regulation may be refused only if such application is manifestly incompatible with the public policy (ordre public) of the forum". It would be important at this stage to highlight how such 'public policy' exception operates and the differences from overriding mandatory provisions provided for in Article 9 of Rome I. Overriding mandatory rules "precede the application of the conflict rule and claim their application whatever the content of the governing law may be". ${ }^{50}$ Conversely, a public policy exception applies "after the conflict rule has determined the governing foreign law". ${ }^{51}$ More specifically, if certain rules are considered to be overriding, the court does not need to apply the foreign law on that point, to see if the result of that application contravenes its public policy. It can simply apply its own rules as overriding. When looking at the public policy exception, however, the court would have to apply the foreign law, unless the result of this application would contravene its public policy. Therefore, in the decision-making process, the court would have to consider the application of the relevant foreign provisions and then proceed to disregard them (as an exception to the applicable law rules of the instrument) if that application's result is against the public policy of the forum. ${ }^{52}$

It is for the national law to determine which rules are overriding mandatory provisions. If Scots law is chosen as the applicable law in a contract of employment then clearly the whistleblower protection, discussed above, would apply. If a choice of a different law is provided under the contract, but the choice of law rules would indicate the application

\footnotetext{
${ }^{47}$ See generally Collins et all, Dicey, Morris and Collins The Conflict of Laws, $15^{\text {th }}$ edn (London, Sweet \& Maxwell, 2012) 2044 ss, paras 33-278 ss, and $4^{\text {th }}$ supplement (2017) 474-477.

${ }^{48}$ Rome I Reg. (n 6) art 9(3).

${ }^{49}$ See discussion in Duarte v Black and Decker Corp [2008] 1 ALL E.R. (Comm) para 55-63.

${ }^{50}$ M Pauknerová, 'Mandatory rules and public policy in international contract law' (2010) 11 ERA forum 29, 31 .

${ }^{51}$ Ibid (emphasis added).

${ }^{52}$ See also indicatively V Pavic, 'Bribery and International Commercial Arbitration - the role of mandatory rules and public policy' (2012) 43 Victoria University of Wellington Law Review 661-687; M Wojewoda, 'Mandatory Rules in Private International Law' (2000) 7 Maastricht Journal of European and Comparative Law 183-213.
} 
of Scots law as the law governing the contract otherwise, then the detriment provisions would apply as non-derogable if the employee works in the UK. ${ }^{33}$ The general rule is that a statute of the United Kingdom will not be applied to a contract unless the governing law of the contract is the law of Scotland, England or Ireland or if it is overriding and applicable despite normal conflict of law rules. ${ }^{54}$ In this regard a provision might be required to be applied to the contract to meet the protection of Article 8, even where a different choice of law is specified, but not be considered an overriding mandatory provision for the purposes of Article 9. This is likely to be significant if there is a difficulty establishing the nature of the employment protection as the article 9 provisions are wider in scope (not limited to employment protection) but Article 9 is of much narrower interpretation (only overriding mandatory provisions, of the law of the forum ${ }^{55}$, or of the law of the place of performance if those overriding mandatory provisions would render the performance of the contract unlawful) ${ }^{56}$.Thus, up to what extent these provisions could also constitute overriding mandatory provisions of the law of the forum in the terms of Art 9 of the Rome I Regulation when the dispute is heard in a court in the UK is of crucial importance and is discussed further below. ${ }^{57}$

As indicated above there are many statutory provisions which regulate the employment relationship which are applicable throughout the legal systems of the UK. Many of these pieces of legislation are non-derogable, as discussed above, so even a contractual choice of law cannot evade the requirements. The ERA ${ }^{58}$ provides that for the purposes of the act it is immaterial what law governs the employment and so it appears to apply to all contracts considered by a UK court and might be considered a non-derogable provision under Article 8. In relation to whistleblowing protection, it will depend on construction of the statutory provisions, such as rights under ERA and PIDA, ${ }^{59}$ in light of the circumstances of the case. ${ }^{60}$ The provisions will apply where the employee is working in the UK but other connections may also be sufficient to establish that the legislation should apply to the facts. There is no "hard and fast rule 61 " but the courts must consider the extent of connection with Great Britain and British employment law.

The effects of statutes, and particularly the question of connection to the UK for the purposes of protection by statutory employment legislation, including whistleblower protection, has been considered by the Employment Appeal Tribunal and the UK Supreme Court. The unfair dismissal case of Ravat $v$ Hilliburton Manufacturing and Services Ltd (Scotland) ${ }^{62}$ established the accepted test in contracts of employment. Where the employee is not undertaking work in the UK then the question is whether the connection is still strong enough to assume that parliamentary intention would be to cover the matter and permit access to an employment tribunal. This case considered whether the complaint of unfair dismissal could be heard in Scotland. The general rule

\footnotetext{
${ }^{53}$ Dicey (n 47) 33-258.

${ }^{54}$ Dicey (n 47) 32-089.

${ }^{55}$ Rome I Reg. (n 6) Art 9 (2).

56 Ibid Art 9 (3).

${ }^{57}$ This is addressed in section 10.6

${ }^{58}$ Employment Rights Act 1996 s204(1).

${ }^{59}$ As discussed above.

${ }^{60}$ Lawson v Serco Ltd [2006] UKHL 3, [2006] I.C.R 250.

${ }^{61}$ Duncombe v Secretary of State for Children, Schools and Families (No.2) [2011] UKSC 36 at 16.

62 Ravat v Hilliburton Manufacturing and Services Ltd (Scotland) [2012] UKSC 1.
} 
is that the place of work is decisive but subject to exceptions. In this case the individual was described as "a UK commuter ${ }^{63 "}$. He resided in Great Britain ${ }^{64}$ but agreed to change his working pattern so that he worked 28 days in Libya and then returned home for 28 days, job sharing with another who did his job in Libya when he was at home. Lord Hope highlighted the difficulties of the facts and consideration of choice of law. ${ }^{65}$ The question is more than one of substantial connection ${ }^{66}$ and when considering an exception to allow jurisdiction where the work takes place away from the UK the connection must be sufficiently strong to justify the exception. The exception being justified on the basis that "parliament must have intended that section 94(1) should apply to ${ }^{67 "}$ the facts. The proper law of the contract was UK and the employee was given assurances that this would continue and so the statutory reach protection should not be altered by the agreement of parties to vary it. These factors were extremely important in identifying the British employment law system ${ }^{68}$ as being that to which the employment had the closest connection.

A subsequent Employment Appeal Tribunal case, ${ }^{69}$ which alleged unfair dismissal as a consequence of making protected disclosures, considered whether this test should be wider for cases of whistleblowing where the public interest of encouraging the whistleblowing would justify the extension. In this case the Italian banking employee with an employment contract and residence in Singapore, worked for a bank in Singapore which had its head office in the UK. It was argued that previous authority established that domestic law ${ }^{70}$ should be used to interpret domestic legislation in a way which is wide enough to give effect to freedom of expression. ${ }^{71}$ It was also argued that the public interest in ensuring the disclosure which had an impact on UK banks justified the extension. Both arguments were rejected finding that the sufficient connection test of Ravat ${ }^{72}$ should be applied.

This section has demonstrated the difficulties that cross-border cases may present to ensure legal protection to whistleblowers who suffer detriment from the employer as a consequence of their actions. Whilst national statutory protection protects domestic workers, those whose employment is cross-border in nature may suffer difficulties in establishing jurisdiction or choice of law. International Private Law rules seek to protect employees from having employment rights eroded by contractual choice of law to their detriment. However, the protection is not uniform and, in cases where there is insufficient connection to the British system, whistleblowers may not be protected and may find that traditional conflicts rules specify a choice of law which provides less

\footnotetext{
63 Ibid para 3.

${ }^{64}$ Ibid. The facts describe the individual working for the appellant (based in Aberdeen) in London from 1990-1995 and at several points the court considered the connection between Great Britain and the employment relationship rather than the constitutent legal systems within the UK (see paras 4, 6, 9, 12 and 14).

${ }^{65}$ Lawson v Serco Ltd (n 60) Quoting Lord Hoffman's speech from para 1.

${ }^{66}$ Ravat (n 62) para 10.

67 ibid, para 12.

68 ibid, para 33.

${ }^{69}$ Smania v Standards Chartered Bank [2014] UKEAT/0181/14.

70 Bleuse v MBT Transport Ltd and another [2007] UKEAT/0339/07.

${ }^{71}$ Council of Europe, The Convention for the Protection of Human Rights and Fundamental Freedoms (European Convention on Human Rights, ECHR) (ETS No 005, 3 September 1953) art 10. Council of Europe, European Social Charter (ETS No 035, 26 February 1965) art 11.

72 Ravat, (n 62) para 55.
} 
protection than they expected. The next section will consider the protection afforded to workers under the right to freedom of expression as provided for by public international law.

\subsection{The contribution of public international law to whistleblowing}

The chapter has thus far discussed the issues of jurisdiction and applicable law raised by instances of cross-border whistleblowing where the nature of the disclosure, or the location in which the disclosure is made, engages a multitude of states and regulatory frameworks. The chapter has identified how such cross-border disclosures generate conflicts of law and has discussed the means by which jurisdiction and the choice of applicable law can be relied upon to find solutions for the whistleblower. As Hyde and Savage demonstrate, however, cross-border whistleblowers still face significant hurdles in receiving protection from detriment for blowing the whistle. ${ }^{73}$

The preceding analysis on these issues does not paint the full picture of the protection a whistleblower can expect. Although the dispute in a cross-border, private sector setting discussed in the chapter may prima facie exclude any meaningful role for public international law, a closer inspection suggests that such a role does exist. This section argues that under international human rights law, and more specifically, the right to freedom of expression as protected in international human rights instruments, states may have a duty to protect whistleblowers who face detriment for proceeding to public interest disclosures. In developing this point, this section will examine firstly, the connection between whistleblowing, human rights law and freedom of expression. It will argue that this relationship suggests that in cross-border disclosures, state obligations under human rights law may require, in specific circumstances, that all states involved in the cross-border disclosure use the means at their disposal to protect whistleblowers from any retaliation they may face for proceeding to disclose information in the public interest. This duty exists regardless of the fact that the dispute between the whistleblower and their employers (who may be based in different states) is one lacking a clear public law element. However, the section will suggest that this duty under international human rights law is not boundless. It will highlight that, in practice, there are significant limits to the protection the cross-border whistleblower can expect under human rights law. After addressing these limitations, the chapter will conclude that although international human rights law may not resolve all issues raised by cross-border whistleblowing, it can serve to incentivise states to more actively seek to ensure that the cross-border whistleblower is not unjustifiably retaliated against. This could include a duty of the courts to rely on overriding mandatory provisions where the human rights of the whistleblower are at stake, especially where the state exercising jurisdiction is party to the European Convention on Human Rights (ECHR or the Convention). This is due to the fact that, as this part will demonstrate, the ECHR whistleblower protection system is particularly advanced with multiple judgments of the European Court of Human Rights (ECtHR or the Court) confirming the link between freedom of expression as protected under Article 10 ECHR and whistleblowing. This suggests that a state that is party to the ECHR would have a Convention-based duty to protect the whistleblower, and this would be a good reason not to apply a foreign law that would result in a violation of a whistleblower's freedom of expression. Therefore,

${ }^{73}$ Hyde and Savage "Whistleblowing without Borders" (n 7). 
this case study on whistleblowing illustrates the link between private and public international law while also identifying the boundaries of this interaction.

\subsubsection{Whistleblowers and Freedom of Expression.}

Freedom of expression is a protected right under the Universal Declaration of Human Rights (UDHR) ${ }^{74}$ and the International Covenant on Civil and Political Rights (ICCPR). ${ }^{75}$ The ICCPR, which aimed to adapt provisions of the UDHR into 'legally binding obligations', ${ }^{\prime} 6$ in Article 19(2) provides that:

Everyone shall have the right to freedom of expression; this right shall include freedom to seek, receive and impart information and ideas of all kinds, regardless of frontiers, either orally, in writing or in print, in the form of art, or through any other media of his choice. ${ }^{77}$

Whistleblowing is an activity that is protected under freedom of expression and has strong support in international human rights law. The connection between whistleblowing and free speech is discussed in reports by the UN Special Rapporteur on freedom of opinion and expression, ${ }^{78}$ while the Special Rapporteur on the right of everyone to the enjoyment of the highest attainable standard of physical and mental health has also focused on the primary role of whistleblowers in alerting the public on misconduct in the healthcare system. ${ }^{79}$ The Special Rapporteur on the situation of human rights defenders in her 2013 report found that ' $[t]$ hose who disclose information of public interest about wrongdoing or illegal activities (whistleblowers), particularly concerning issues of corruption of public officials, face a high risk of retaliation' 80 and stressed that 'Articles 32 and 33 of the United Nations Convention against Corruption underscore the need to protect the rights of whistle-blowers and witnesses of corruption'. 81 Finally, the 2015 report of the Special Rapporteur on the Promotion and the Protection of the Right to Freedom of Opinion and Expression addressed the issues surrounding the protection of sources of information and whistleblowers, arguing that 'basic protections [for confidential sources and whistleblowers] are critical to an effective right to freedom of expression, accountability and democratic governance'. ${ }^{82}$

\footnotetext{
74 Universal Declaration of Human Rights, UNGA Res 217 A(III) (10 December 1948) (UDHR) art 19.

75 International Covenant on Civil and Political Rights, UNTS 171, 16 December 1966 (ICCPR) art 19.

76 P Alston, R Goodman and HJ Steiner, International Human Rights In Context: Law, Politics, Morals - Texts and Materials, 3rd edn (Oxford, Oxford University Press, 2007) 263.

77 ICCPR art 19(2).

78 "Individuals should be protected from any legal, administrative or employment-related sanctions for releasing information on wrongdoing, viz. the commission of a criminal offence or dishonesty, failure to comply with a legal obligation, a miscarriage of justice, corruption or dishonesty or serious failures in the administration of a public body". UNCHR, 'Civil and Political Rights including the question of Freedom of Expression' (18 January 2000) E/CN.4/2000/63, para 44.

${ }^{79}$ UNCHR, 'Report of the Special Rapporteur on the right of everyone to the enjoyment of the highest attainable standard of physical and mental health, Anand Grover' (10 April 2012) A/HRC/20/15, para 26. 80 UNCHR, 'Report of the Special Rapporteur on the situation of human rights defenders, Margaret. Sekaggya: Mission to Ireland (19-23 November 2012)' (26 February 2013) A/HRC/22/47/Add.3, para 92. 81 Ibid.

82 UNGA, 'Report of the Special Rapporteur on the promotion and protection of the right to freedom of opinion and expression' (8 September 2015) A/70/361.
} 
At the regional level, in the Council of Europe (COE), the Civil Law Convention on Corruption (1999) requires each party to 'provide in its internal law for appropriate protection against any unjustified sanction for employees who have reasonable grounds to suspect corruption and who report in good faith their suspicion to responsible persons or authorities' ${ }^{83}$ Furthermore, the Parliamentary Assembly of the COE with Resolution 1729 (2010) on the protection of whistleblowers, recognised the connection between 'concerned individuals who sound an alarm' and the objective of strengthening accountability and bolstering 'the fight against corruption and mismanagement, both in the public and private sectors' ${ }^{84}$ It explicitly prompted member states to adopt comprehensive whistleblowing legislation that would cover 'both public and private sector whistleblowers'. ${ }^{85}$ Finally, Parliamentary Assembly Resolution 2060 (2015) on 'Improving the Protection of Whistle-blowers', stressed 'the importance of the case law of the European Court of Human Rights (ECtHR), upholding the right to privacy, freedom of speech and the protection of whistle-blowers' ${ }^{86}$ Thus, apart from the soft law instruments discussed above, in its case-law, the ECtHR has fully embraced the notion that whistleblowing falls within the ambit of Article 10 of the ECHR, which protects freedom of expression. With the landmark judgment in Guja v Moldova, ${ }^{87}$ 'the first case to deal explicitly with the practice of whistleblowing', ${ }^{8}$ the ECtHR established the criteria a whistleblower had to satisfy in order to claim protection under freedom of expression for any retaliation they faced. ${ }^{89}$ Furthermore, this judgment provided valuable insight into the circumstances under which a contracting party to the ECHR would be in breach of its obligations for not protecting the whistleblower from retaliation. While recognising that the very nature of employment requires that workers are bound 'by a duty of loyalty and discretion', 90 the Court held that a worker:

in the course of his work, may become aware of in-house information, including secret information, whose divulgation or publication corresponds to a strong public interest. The Court thus considers that the signaling [...] of illegal conduct or wrongdoing in the workplace should, in certain circumstances, enjoy protection. This may be called for where the employee or civil servant concerned is the only person, or part of a small category of

\footnotetext{
${ }^{83}$ Council of Europe, Civil Law Convention on Corruption (ETS No 174, 1 November 2003) Art 9. Emphasis added.

84 Council of Europe Parliamentary Assembly, Resolution 1729 (2010) 'On the protection of whistleblowers'.

85 ibid, para 6.1.2.

${ }^{86}$ Council of Europe Parliamentary Assembly, Resolution 2060 (2015) 'Improving the protection of whiste-blowers' para 4.

${ }^{87}$ Guja v Moldova App no 14277/04 (ECtHR, 12 February 2008).

${ }^{88}$ B Rainey, E Wicks and C Ovey, Jacobs, White and Ovey: The European Convention on Human Rights, 7th edn (Oxford, Oxford University Press, 2017) 442.

${ }^{89}$ More specifically, the ECtHR provided free speech protection for public disclosures of information on wrongdoing if the whistleblower could demonstrate: a) that they had made use of other means to raise concern if these were available to them (for instance internal mechanisms for raising concerns within their institution or regulatory bodies), b) the interest in disclosing the information outweighed the interest in keeping the information secret or the interest in protecting the reputation of the empoyer, c) in disclosing the information, they did not act for personal gain or due to a personal grievance against their employer. On this see D Kagiaros, 'Protecting 'national security' whistleblowers in the Council of Europe: an evaluation of three approaches on how to balance national security with freedom of expression' (2015) 19 The International Journal of Human Rights especially 411- 413.

90 Guja v Moldova, para 70.
} 
persons, aware of what is happening at work and is thus best placed to act in the public interest by alerting the employer or the public at large. ${ }^{91}$

The Court in this case found that the detriment suffered by a civil servant for revealing to the press irregularities in the Special Prosecutor's office violated Article 10 ECHR. The approach of the ECtHR in this case has been confirmed in a series of subsequent judgments which broadly share the same facts. ${ }^{92}$ The protection offered to whistleblowers under Article 10 ECHR in the Guja case was directed to public sector employees, this, however, does not preclude private sector employees from seeking similar protection. The ECtHR has accepted ${ }^{93}$ that protections under free speech may require employers in the private sector to ensure that any sanctions on their employees are imposed 'in a manner compatible with Convention expectations' ${ }^{94}$ Furthermore, states undertake an obligation to ensure that 'employment tribunals can provide effective redress [...] where an employee's dismissal constitutes a manifestly disproportionate sanction'. 95 This obligation will be further developed and explained in the following section.

\subsection{Which states are responsible for providing protection in a cross-border disclosure?}

As the previous section has explained, the practice of whistleblowing engages the whistleblower's right to free speech. As freedom of expression is a qualified right, in order to avoid being found in breach of its international human rights law obligations, a state must ensure that any interference or restriction to this right must be prescribed by law, must serve a legitimate aim and must be necessary in a democratic society. ${ }^{96}$ In the context of cross-border disclosures, however, there is more than one state that may owe human rights obligations to the whistleblower. Apart from the state in which the disclosure is made, there is a possibility that other states involved in the cross-border disclosure may have human rights obligations towards the whistleblower. This section argues that while there is little doubt that the state of disclosure has obligations towards the whistleblower under human rights law, the state whose courts exercise jurisdiction, would also have human rights obligations in this context. Both propositions will be examined in turn.

\subsubsection{The state in which the disclosure took place.}

The state in which the disclosure took place has the primary responsibility of ensuring that a whistleblower disclosing information in the public interest within its jurisdiction is not subjected to disproportionate sanctions. As discussed above, this would apply even where the employment relationship is in the private sector. This is due to the fact that human rights obligations under international law are not limited to

\footnotetext{
91 ibid, paras 72, 75. See also J Lewis, J Bowers, M Fodder and J Mitchell, Whistleblowing: Law and Practice (Oxford, Oxford University Press, 2012) 11.140, 11.141.

92 See Heinisch $v$ Germany App no 28274/08 (ECtHR, 21 July 2011); Bucur and Toma v Romania App no 40238/02, (ECtHR, 8 January 2013); Matuz v Hungary App no 73571/10 (ECtHR, 21 October 2014).

93 Fuentes Bobo v Spain App no 39293/98 (ECtHR, 29 February 2000).

${ }_{94}$ RJ Reed and JL Murdoch, Human Rights Law in Scotland (4th edn, Bloomsbury Professional 2017 ) 904.

95 ibid quoting Palomo Sanchez and others v Spain App nos 28955/06, 28957/06, 28959/06, 28964/06 (ECtHR, 12 September 2011).

96 ECHR art 10(2), ICCPR art 19(3).
} 
the negative type of protection that traditionally is synonymous with civil and political rights, and calls upon the state to refrain from any unwarranted interference with the enjoyment of a right. ${ }^{97}$ There is also a positive dimension which requires the state to act preventatively and to protect the individual from wrongful acts that threaten the enjoyment of her rights and are attributable to third persons or general situations. ${ }^{98}$ This duty also includes the obligation to provide redress to the victim of a violation by a third party, to carry out investigations on the facts surrounding the violation ${ }^{99}$ or to punish the third-party wrongdoer. This positive dimension of rights is where the obligation of states to protect whistleblowers employed in the private sector would be located, as it requires the state to take action, or at least not to remain passive, in order protect the rights-holder from sanctions that could engage international human rights obligations, namely freedom of expression. The existence of this obligation creates a further incentive on the state to ensure that their whistleblower protection framework provides sufficient remedies to whistleblowers for their public interest disclosures, especially in sectors with high corruption rates, such as the financial sector, where disclosures of wrongdoing would be particularly beneficial.

In practice, however, there are limits as to how this protection under free speech has been successfully applied at the domestic level to benefit whistleblowers. The degree to which the whistleblower will be able to rely on freedom of expression in the state where the information is disclosed is conditional on the extent to which the state in question implements its international human rights obligations by effectively protecting whistleblowers through its employment law or other legal regime. For instance, as Vaughn argues, 'in countries that view constitutional or human rights protections as limiting government rather than requiring it to protect its citizens'100 such as the US, there could be a situation where the domestic constitutional framework 'imposes few affirmative obligations on government'. ${ }^{101}$ According to Vaughn, in the US, 'this lack of affirmative duties applies to freedom of expression'.102

Another important factor in this context would be the degree to which domestic courts recognise the link between freedom of expression and whistleblowing. As the relationship between the two is still nascent, it may not be possible for a whistleblower to utilise free speech in their favour in a whistleblowing dispute, especially where they have to rely on the persuasive value of international instruments, such as reports by special rapporteurs, that do not generate binding legal obligations on states. ${ }^{103}$ Even in a state that is a party to the ECHR, which, as discussed above, has articulated clearer

\footnotetext{
${ }^{97}$ See A Mowbray, The Development of Positive Obligations Under the European Convention on Human Rights by the European Court of Human Rights (Hart 2004).

${ }^{98}$ For this see $X$ and $Y v$ the Netherlands App no 8978/80 (ECtHR, 26 March 1985) and in the InterAmerican Court of Human Rights, Velásquez-Rodríguez v Honduras (Merits), Ser C, No 4, (1988), paras 172-175 and Ximenes-Lopes v Brazil, Ser C, No 149 (2006) 55/96.

${ }^{99}$ See for instance Nachova and others $v$ Bulgaria App nos 43577/98 and 43579/98 (ECtHR, 6 July 2005).

100 R Vaughn, The Successes and Failures of Whistleblower Laws (Cheltenham, Edward Elgar, 2012) 297.

101 ibid.

102 ibid.

103 The persuasive value of such instruments and soft law in general at the domestic level is contested. For example, on the use of treaty bodies' general comments in domestic case law, see K McCall-Smith, 'Interpreting International Human Rights Standards: Treaty Body General Comments as a Chisel or Hammer?' in S Lagoutte, T Gammeltoft-Hansen, J Cerone (eds), Tracing the Role of Soft Law in Human Rights (Oxford, Oxford University Press, 2016). See chapter by Albornoz and Collins, in this volume.
} 
standards of whistleblower protection under free speech, it may not be easy to identify the impact this has had at the domestic level. As Hyde and Savage explain, relying on the UK as an example, it may be difficult to determine the extent to which UK employment tribunals sufficiently take into account the Strasbourg jurisprudence on free speech and whistleblowing when examining whistleblower claims. ${ }^{104}$

Nevertheless, the positive obligations imposed on states to protect the rightsholder can play an important role in galvanising more active involvement to protect the whistleblower who is 'caught up' in a cross-border disclosure. As the international human rights law protection framework builds on its understanding of the connection between free speech and whistleblowing, states will be required to demonstrate that they have not remained passive where a foreign whistleblower faces detriment from a private entity within their jurisdiction. Apart from human rights law however, there are further incentives for the state where the disclosure takes place to ensure that such whistleblowers are not retaliated against. As Hyde and Savage argue, 'the legal jurisdiction which benefits from the disclosure' 105 may want to protect its citizens from the misconduct the whistleblower has uncovered, or in the case of financial services, it may want to recoup significant sums from tax evasion, cartel schemes or other types of financial impropriety in which private entities could engage. Therefore, states may have good reasons to build international cooperation mechanisms, through treaties, international agreements and soft law instruments to ensure better exchange of information between various regulators, or to set clearer standards on whistleblower protection in this context.

But returning to the key theme of the volume, namely the interaction between private and public international law, the following section will argue that even the state whose courts exercise jurisdiction over the employment dispute owes human rights obligations to the whistleblower. The following section will argue that this may impact the approach the court follows when applying rules of private international law. The section will primarily focus on states who are party to the ECHR as it is the human rights regime offering the most advanced protection to whistleblowers.

\subsubsection{Human Rights and private international law in the context of cross-border whistleblowing}

As the previous part demonstrated, the ECHR system, by linking any retaliation whistleblowers faced for a public interest disclosure to a violation of Article 10 ECHR, has clearly articulated state obligations towards whistleblowers under the Convention. Relying on the example of the ECHR, and its particularly well-developed regime of whistleblower protection, it would be important to assess the impact of Convention rights to the choice of applicable law in the whistleblowing scenario the chapter examines, where the state whose courts are hearing the dispute is different to the state in which the disclosure took place. How should a contracting party to the ECHR employ the tools of private international law to ensure that it upholds its Convention obligations? Would the state's human rights obligations take precedence over what the

104 '[B]ecause the employment tribunal judgments are placed on a closed register, it is difficult for researchers to determine the application and effectiveness of these provisions in practice' Hyde and Savage, 'Whistleblowing without borders' (n 7) 7.

105 ibid, 3. 
framework of private international law dictates in relation to the applicable law? In addressing this issue, this part argues that where the choice of law rules point to a foreign law, the application of which would result in the violation of a contracting party's obligations under the ECHR, ${ }^{106}$ the contracting party in question would have a human rights obligation to protect the whistleblower from this foreign law, as the court would be expected to ensure that any outcome in the dispute before it would not violate the whistleblower's Article 10 ECHR rights. In relation to the interaction between the ECHR and private international law, as Kiestra notes, 'there is not much case law in which the [European] Court [of Human Rights] has examined the impact of the rights guaranteed in the ECHR on the applicable law in private international law'.107

Nevertheless, this issue has 'spawned lively debate in the literature'. ${ }^{108}$ While there may not be a conclusive approach in this regard, the chapter argues, for reasons that will be developed below, that there are good reasons for a court exercising jurisdiction to make use of the concept of 'overriding mandatory provisions' discussed above to address the plight of the whistleblower.

In his analysis on the impact of the ECHR to private international law, Kiestra explains, that Article 1 ECHR requires contracting parties to "secure to everyone within their jurisdiction the rights and freedoms defined" 109 in the Convention. Where the law of a non-contacting party to the Convention is applied, Kiestra argues that the state applying the foreign law would be in violation of its Convention obligations if the application of the law would violate the ECHR. ${ }^{110}$ Where the foreign law belongs to another contracting party to the ECHR, Kiestra envisions a situation where the two states would both be 'co-responsible'111 if the application of the foreign law constitutes a Convention violation. ${ }^{112}$ This analysis provides a useful starting point to examine the impact of human rights, or more broadly public international law, to the private international law issues discussed in the first part of the chapter.

Where a court exercising jurisdiction in a case to determine whether any sanction the whistleblower experienced for proceeding to a public interest disclosure in another state was lawful, if choice of law rules point to the application of foreign law, the court must still take into account its own state's human rights obligations. This could mean that the court should be more inclined to make use of the flexibility provided under Article 9 Rome I to protect the whistleblower from any type of sanction that would violate his freedom of expression. This would apply regardless of whether the foreign state whose law is to be applied is a contracting party to the Convention or not.

This is an important facet of the state's positive obligations under international human rights law. Where positive obligations are concerned, the state is asked to

\footnotetext{
${ }^{106}$ See L Kiestra, The Impact of the European Convention on Human Rights on Private International Law (Den Haag, T.M.C. Asser Press, 2014) 150.

107 ibid.

108 ibid.

${ }^{109} \mathrm{ECHR}$, art 1.

${ }^{110}$ Kiestra relies on the admissibility decision of Ammdjadi v. Germany (dec.), no. 51625/08, 9 March 2010 to illustrate this point, Kiestra, 'The Impact' (n 106) 152.

111 ibid, 153.

112 ibid. Kiestra concludes that in fact the possibility of such co-responsibility has not been accepted by the Strasbourg organs.
} 
activate, as far as possible, those means at its disposal which are suitable to realise the goal of preventing and stopping any wrongful conduct that will result in the violation of the rightsholder's rights. As far as the means are concerned, the state has the discretion to select the one that it prefers between equally fruitful means. ${ }^{113}$ The state's response is assessed based on the circumstances of the particular case. More specifically, it is based on doing what was necessary to avert the unwanted result and also what it could do as far as the means at its disposal, as well as other related parameters, such as whether or not based on the facts of each separate case, it was in a position to know and predict the imminent danger of a human rights violation. ${ }^{114}$

Applying this to the scenario at hand, the means the state has at its disposal to offer protection to the cross-border whistleblower are the rules giving it the flexibility to disregard (via the public policy exception, Article 21 of the Rome I Regulation) or override foreign law (via the provisions in Article 9 of the Rome I Regulation as discussed above), if the outcome of applying the foreign law would be an ECHR violation. Therefore, in such a state, regardless of what the foreign law mandates in relation to whistleblower protection, the court would attempt, to the best of its abilities, to ensure that the whistleblower's rights are not violated. This approach of giving precedence to human rights obligations is not foreign to courts in the UK. In the case of Kuwait Airways Corporation v Iraqi Airways Company and Others (Nos 4 and 5) ${ }^{115}$ for instance, Lord Nicholls noted that:

When deciding an issue by reference to foreign law, the courts of this country must have a residual power, to be exercised exceptionally and with the greatest circumspection, to disregard a provision in the foreign law when to do otherwise would affront basic principles of justice and fairness which the courts seek to apply in the administration of justice in this country. Gross infringements of human rights are one instance, and an important instance, of such a provision. ${ }^{116}$

Therefore, as the human rights framework develops in the direction of stronger human rights protection for whistleblowers, especially in cases where they disclose transnational financial crimes that may potentially impact on more than one state, courts applying rules of private international law will have increasingly convincing reasons to follow an approach that gives primacy to the whistleblower's rights under freedom of expression. An important caveat to this analysis, however, is that this proposition the paper advances has yet to fully be tested in practice. It is hoped that the clear trend in adding human rights to the armoury of whistleblowing protection will allow courts to more effectively discharge their duties in protecting cross-border whistleblowers from unwarranted retaliation.

\subsection{Conclusions}

\footnotetext{
113 T Stephens (Rapporteur) and D French (Chair), ILA Study Group on Due Diligence in International Law Second Report (July 2016) available at ... This report suggests that 'states have significant latitude in the choice of means they employ when taking all measures they could reasonably be expected to take' at 7 .

${ }^{114}$ See in detail O De Schutter, International Human Rights Law, 2nd edn (Cambridge, Cambridge University Press, 2014) $462-518$.

115 [2002] UKHL 19.

116 ibid, [18].
} 
This case study of whistleblowing in the financial sector has attempted to compare the frameworks of public and private international law and to define their interactions and boundaries. The first part of the chapter has highlighted the approaches under private international law in this sphere. The second part went on to assess whether state obligations under international human rights law could provide additional protection to whistleblowers under these circumstances. As far as the state where a disclosure takes place is concerned, human rights law has a significant role to play. Developing international standards tying retaliation against whistleblowers to free speech violations, require states to take action to ensure that whistleblowers do not face detriment within their jurisdictions for proceeding to public interest disclosures. This would also apply in cases where the whistleblower faces retaliation from a private entity. If the courts hearing the dispute are in a different state from the state in which the disclosure took place, the obligations under human rights law may require the court to apply private international law rules in a manner that protects the whistleblower's rights under free speech. There are however particularly strong reasons for states to agree at the international level to take further steps both in private and public international law frameworks to better protect individuals involved in cross-border whistleblowing from retaliation. 